\title{
Sulfa-drugs as Topic for Secondary School Chemistry - Effects, Side Effects and Structural Causes
}

\author{
Roger Deuber ${ }^{a \star}$, Urs Leisinger ${ }^{\mathrm{b}}$, and Amadeus Bärtsch ${ }^{\mathrm{c}}$
}

\begin{abstract}
The topic 'Sulfa-Drugs in secondary school chemistry' has been developed in cooperation of three high schools (Kantonsschulen). Three essential aspects are covered that ideally complement each other: 1 . The synthesis of sulfamethoxazole - an antibiotic 'without side effects' - as a practical course in a school laboratory; 2. An introduction to the topic 'drug design' with the question of structure, effect and side effects of sulfonamides; 3 . A detailed answer to the question of how side effects can be avoided by the design of drugs using molecular modelling. Teaching materials on all topics can be downloaded free of charge from Swisseduc.ch (see box). The article discusses various possible approaches in high school chemistry along the lines of a well-established teaching unit on sulfonamides.
\end{abstract}

Keywords: Antibiotics · Drug design · Education - Enzyme inhibitor · High school chemistry · Molecular modelling $\cdot$ Side effects $\cdot$ Sulfamethoxazole $\cdot$ Sulfanilamide $\cdot$ Sulfonamides $\cdot$ Synthesis

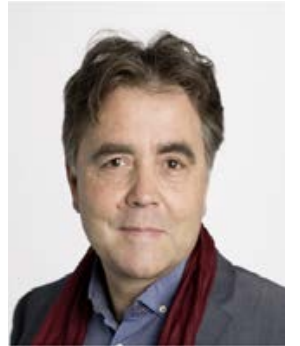

Roger Deuber studied biochemistry at the University of Zurich, graduating with a Diploma in 1987 under the supervision of Prof Dr. C. Schlatter. After receiving the Diploma for Teaching at higher secondary schools for chemistry and later also biology (Höheres Lehramt) from the University of Zurich, he has taught chemistry at the Kantonsschule Baden since 1992. Since 2002, he is a member of the executive board of the Association of Swiss nature science teachers (VSG). In 2010 he was awarded the Balmer Prize of the Swiss Chemical Society for innovations in the teaching of chemistry. Since the beginning of swisseduc.ch, he is a member of the team responsible for the chemistry websites.

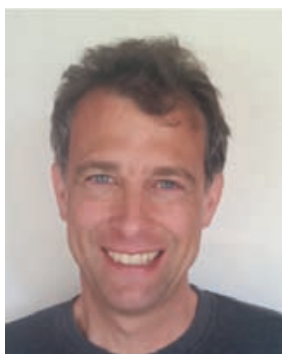

Urs Leisinger studied environmental sciences at the Swiss Federal Institute of Technology in Zurich (ETHZ), including a semester at the Plant and Pollution Research Laboratory in Tallinn, Estonia. He received his $\mathrm{PhD}$ for work on the response to oxidative stress in green algae under the supervision of Rik Eggen, EAWAG Dübendorf, in 2001. In 2004, he obtained his Certificate in Education at the ETH and since 2001, he works as a chemistry teacher at the Kantonsschule Zug. In 2016 he has joined the team responsible for the chemistry websites at swisseduc.ch.

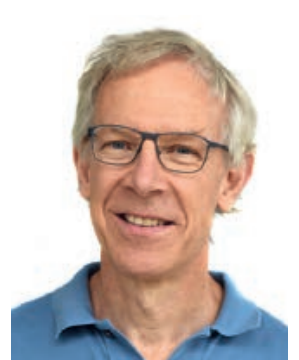

Amadeus Bärtsch studied chemistry at the University of Zurich. The diploma thesis in organic synthesis was followed by a $\mathrm{PhD}$ under the supervision of Prof. W. K. Lutz and Prof. C. Schlatter at the ETH on the binding of chlorinated solvents to DNA for the assessment of carcinogenicity. After teaching chemistry at the Kantonsschule Sargans during his $\mathrm{PhD}$ he moved to the Kantonsschule Freudenberg in Zurich. Since 2009 he has been involved in the teacher training of the ETH and the University of Zurich and is responsible for the didactic and practical modules in chemistry.

\section{Synthesis and Antibiotic Effect of Sulfanilamide}

A few years ago, a teaching unit on the effect of sulfanilamide as an antibiotic, developed by chemistry teachers at the Kantonsschule Baden, was published in the journal for chemistry didactics Praxis der Naturwissenschaften - Chemie PdN. ${ }^{[1]}$ In this teaching unit, students work independently, learn about the importance of folic acid and understand that sulfonamides inhibit the enzyme dihydropteroate synthase DHPS, which bacteria need to grow. Since humans do not have this enzyme - the folic acid is obtained from diet - antibiotically active sulfonamides can be used as a specifically acting drug against bacterial infections (Figs 1 and 2).

A central part of the teaching unit is the chemical synthesis of sulfanilamide, which can be carried out by the students in the lab after a careful theoretical introduction with the help of detailed instructions. The product and the intermediates can be identified by IR spectroscopy and the students can themselves examine the antibiotic effect of the obtained sulfanilamide by means of a disc diffusion test. The teaching unit can be downloaded free of charge from the education server https://www.swisseduc.ch. ${ }^{[2]}$

The teaching unit has since been successfully carried out at many Swiss high schools (Kantonsschulen) and has also led to several Matura theses (Maturaarbeiten). ${ }^{[3,4]}$ 


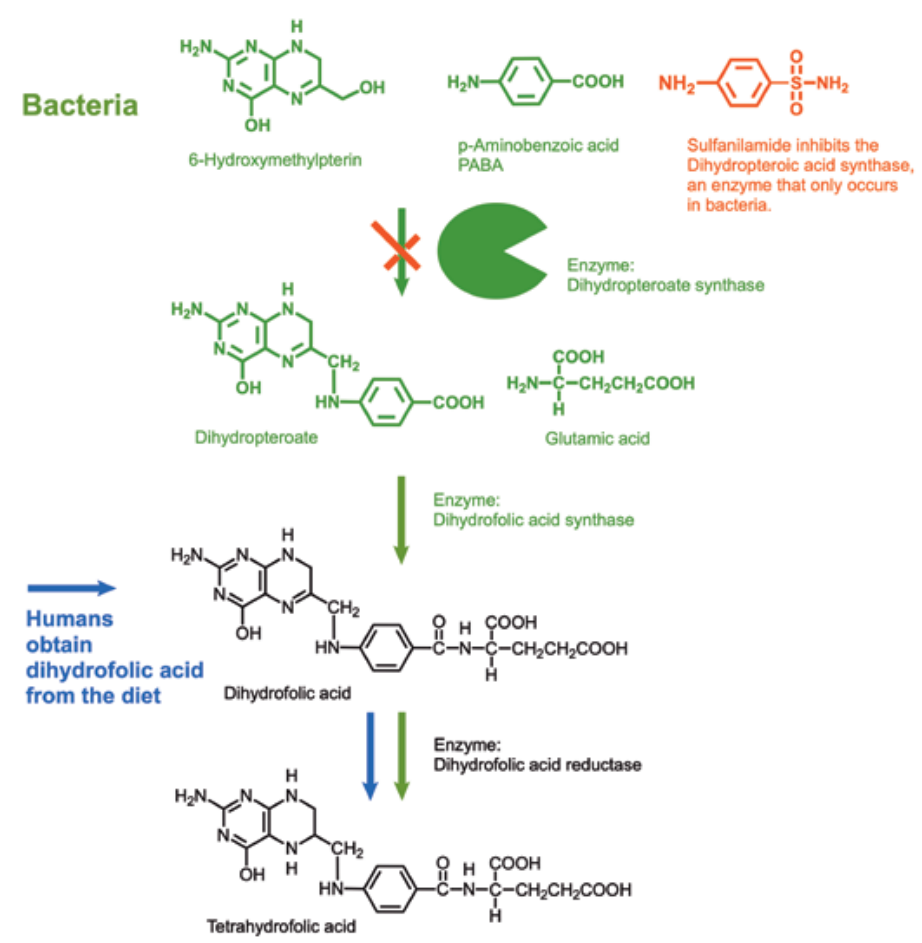

Fig. 1. Sulfonamides inhibit the first stage of the folic acid synthesis and thus the growth of bacteria. The human organism also depends on folic acid. However, unlike bacteria, humans take up dihydrofolic acid with their food. Sulfonamides therefore act specifically against bacteria

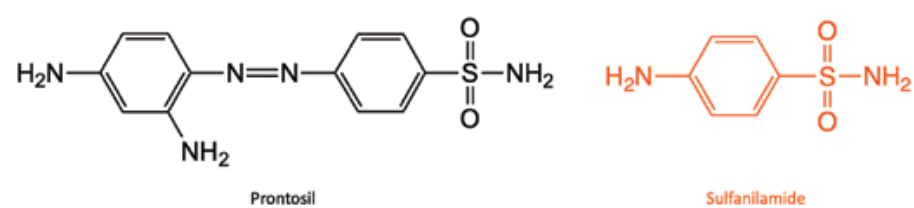

Fig. 2. The bacteriostatic sulfanilamide is formed in higher organisms by the metabolic degradation of the azo dye prontosil

The discovery of sulfanilamide is of historical interest: it is the first representative of the sulfonamides to be used as a drug in human medicine due to its antibiotic effect. The success story of sulfanilamide began with prontosil, an azo dye synthesized in 1932 by the Bayer company. In the same year, Gerhard Domagk discovered that prontosil had an antibacterial effect. For this achievement, he received the Nobel Prize in 1939. Sulfanilamide was then discovered in 1935 at the Institute Pasteur in Paris as the active substance of prontosil.

Soon after, sulfanilamide also became known in the USA especially when the son of US President Franklin D. Roosevelt was saved from a serious infection in 1936. ${ }^{[5,6]}$

Sulfanilamide and other sulfonamides had their heyday during the Second World War, when they were used in Germany to treat wound infections of war injuries because penicillin was not available.

In the search for antibiotics with fewer side effects, with broader efficacy against microorganisms but also new medical applications, by the end of the 1930s, over 1000 derivatives of sulfanilamide were synthesized, many of which are still in use in human medicine today (see Table 1). ${ }^{[5,6]}$

Over time, sulfanilamide and a great number of other antibiotically active sulfonamides lost their approvals as drugs in human medicine. The reason were side effects, among them a diuretic effect and the inhibition of aqueous humour formation in the eye. In the late 1930s, there was increasing evidence that patients treated with sulfonamides for bacterial infections had increased urination. Shortly after the enzyme carbonic anhydrase was discovered in 1932, it was found that the diuretic effect was due to inhibition of carbonic anhydrase by sulfonamides in the kidney. Starting with sulfanilamide, the search therefore began for derivatives that could be used as diuretics. ${ }^{[5,6]}$

This historical background was the starting point for the three authors of this article to expand the original teaching unit didactically in a significant way - in three respects:

1. The development of a lab course for students of secondary schools on the synthesis of a modern sulfonamide that only inhibits enzymes in bacteria but not carbonic anhydrase in humans - and thus does not have the side effects of sulfanilamide. This was achieved a year ago with a Matura thesis on the synthesis of sulfamethoxazole at the Kantonsschule Baden. Sulfamethoxazole had been chosen because it is widely used as an antibiotic, e.g. in Bactrim ${ }^{\circledR}$.

2. The discussion about the structure-activity relationship (SAR) of sulfonamides, i.e. the explanation at the molecular level why sulfanilamide inhibits both enzymes while sulfamethoxazole only blocks the bacterial enzyme and modern sulfonamide-type carbonic anhydrase inhibitors impact only the human carbonic anhydrase. This allows the students to gain new insights into the possibilities of modern drug design.

3. The methodology of molecular modelling makes it possible for the students to understand interactively and independently on a molecular level, spatially and through the concretely acting forces, why drugs like sulfamethoxazole inhibit some enzymes and do not affect others.

\section{The Synthesis of Sulfamethoxazole as an Antibiotic Sulfonamide 'without Side Effects'}

When a secondary school chemistry teacher wants to carry out a complex synthesis of an organic substance such as sulfamethoxazole as a lab work for students, he or she is faced with a variety of challenges:

1. The most suitable publication for the synthesis must be found and adapted, whereby the adaptation must fulfil the following criteria:

- Compliance with the strict safety regulations for schools

- Implementation with the equipment commonly used in schools, which, in addition to the actual synthesis, also applies to the analysis of the product and intermediates.

- The sometimes very tight time and financial framework within the existing teaching conditions provided by the school.

2. It takes a lot of experience and also a lot of time to successfully adapt the synthesis. In the everyday life of a teacher with a full workload, this is almost impossible.

Unlike the synthesis of sulfanilamide, that has already been established as a high school experiment in 2008, the synthesis of sulfamethoxazol is challenging. It was therefore a stroke of luck that in 2018 there were two talented students from the Kantonsschule Baden who had the opportunity to adapt the synthesis of sulfamethoxazole in the context of a Matura thesis at the Institute of Pharmaceutical Sciences of the ETHZ under the supervision of Prof. Dr. Karl-Heinz Altmann. Christian Bold, who had completed an internship at the Kantonsschule Baden shortly before, had made the contact. He is writing his dissertation there and has also taken on co-supervision of the Matura thesis. ${ }^{[9]}$

The Matura team found two publications for the synthesis of sulfamethoxazole in the literature, which they used as a basis for their own experiments. ${ }^{[10,11]}$

The following changes in the original synthesis procedure were crucial for a successful implementation as a chemistry practical course at a high school:

Performing the reaction with THF under reflux at boiling temperature instead of room temperature accelerated the third step 
Table 1. Sulfonamides still used as antibiotics in human medicine today ${ }^{[7,8]}$

\begin{tabular}{|c|c|c|c|c|}
\hline Structure & INN-Name & Molecular Formula & IUPAC-Name & Usage \\
\hline & Sulfanilamide & $\mathrm{C}_{6} \mathrm{H}_{8} \mathrm{~N}_{2} \mathrm{O}_{2} \mathrm{~S}$ & $\begin{array}{l}\text { 4-aminobenzene } \\
\text { sulfonamide }\end{array}$ & $\begin{array}{l}\text { Basic structure } \\
\text { of sulfonamides }\end{array}$ \\
\hline & Mafenide & $\mathrm{C}_{7} \mathrm{H}_{10} \mathrm{~N}_{2} \mathrm{O}_{2} \mathrm{~S}$ & 4-(aminomethyl)benzenesulfonamide & $\begin{array}{l}\text { Antibiotic for } \\
\text { burns }\end{array}$ \\
\hline & Sulfacarbamide & $\mathrm{C}_{7} \mathrm{H}_{9} \mathrm{~N}_{3} \mathrm{O}_{3} \mathrm{~S}_{2}$ & $\begin{array}{l}\text { 4-amino- } N \text {-carbamoylbenzenesulfon- } \\
\text { amide }\end{array}$ & $\begin{array}{l}\text { Antibiotic for } \\
\text { urinary tract } \\
\text { infections }\end{array}$ \\
\hline & Sulfacetamide & $\mathrm{C}_{8} \mathrm{H}_{10} \mathrm{~N}_{2} \mathrm{O}_{3} \mathrm{~S}$ & $N$-[(4-aminophenyl)sulfonyl]acetamide & $\begin{array}{l}\text { Antibiotic for } \\
\text { acne }\end{array}$ \\
\hline & Sulfadiazine & $\mathrm{C}_{10} \mathrm{H}_{10} \mathrm{~N}_{4} \mathrm{O}_{2} \mathrm{~S}$ & $\begin{array}{l}\text { 4-amino- } N \text {-pyrimidin- 2-yl-benzenesul- } \\
\text { fonamide }\end{array}$ & $\begin{array}{l}\text { Antibiotic for } \\
\text { internal } \\
\text { and external } \\
\text { infections }\end{array}$ \\
\hline & Sulfalene & $\mathrm{C}_{11} \mathrm{H}_{12} \mathrm{~N}_{4} \mathrm{O}_{3} \mathrm{~S}$ & $\begin{array}{l}\text { 4-amino- } N \text {-(3-methoxypyrazin-2-yl) } \\
\text { benzensulfonamid }\end{array}$ & Antibiotic \\
\hline & $\begin{array}{l}\text { Sulfamethoxa- } \\
\text { zole }\end{array}$ & $\mathrm{C}_{10} \mathrm{H}_{11} \mathrm{~N}_{3} \mathrm{O}_{3} \mathrm{~S}$ & $\begin{array}{l}\text { 4-amino- } N \text {-(5-methyl-1,2-oxazol-3-yl) } \\
\text { benzensulfonamid }\end{array}$ & $\begin{array}{l}\text { Antibiotic for } \\
\text { urinary tract } \\
\text { infections }\end{array}$ \\
\hline & $\begin{array}{l}\text { Sulfamethoxyd- } \\
\text { iazine }\end{array}$ & $\mathrm{C}_{11} \mathrm{H}_{12} \mathrm{~N}_{4} \mathrm{O}_{3} \mathrm{~S}$ & $\begin{array}{l}\text { 4-amino- } N \text {-(5-methoxypyrimidin-2-yl) } \\
\text { benzensulfonamid }\end{array}$ & $\begin{array}{l}\text { Antibiotic for } \\
\text { leprosy }\end{array}$ \\
\hline & $\begin{array}{l}\text { Sulfametomi- } \\
\text { dine }\end{array}$ & $\mathrm{C}_{12} \mathrm{H}_{14} \mathrm{~N}_{4} \mathrm{O}_{3} \mathrm{~S}$ & $\begin{array}{l}\text { 4-amino- } N \text {-(6-methoxy-2-methylpyrimi- } \\
\text { din-4-yl)benzenesulfonamide }\end{array}$ & $\begin{array}{l}\text { Antibiotic for } \\
\text { internal infec- } \\
\text { tions }\end{array}$ \\
\hline & Sulfametrole & $\mathrm{C}_{9} \mathrm{H}_{10} \mathrm{~N}_{4} \mathrm{O}_{3} \mathrm{~S}_{2}$ & $\begin{array}{l}\text { 4-amino- } N \text {-(4-methoxy-1,2,5-thiadiazol- } \\
\text { 3-yl)benzenesulfonamide }\end{array}$ & $\begin{array}{l}\text { Antibiotic for } \\
\text { internal } \\
\text { infections }\end{array}$ \\
\hline & Sulfamoxole & $\mathrm{C}_{11} \mathrm{H}_{13} \mathrm{~N}_{3} \mathrm{O}_{3} \mathrm{~S}$ & $\begin{array}{l}\text { 4-amino- } N \text {-(4,5-dimethyl-1,3-oxazol- } \\
\text { 2-yl)benzenesulfonamide }\end{array}$ & $\begin{array}{l}\text { Antibiotic for } \\
\text { internal } \\
\text { infections }\end{array}$ \\
\hline & Sulfisalizine & C18H14N4O5S & $\begin{array}{l}\text { 2-hydroxy-5-[[4-(pyridin-2-ylsulfamoyl) } \\
\text { phenyl]diazenyl]benzoic acid }\end{array}$ & $\begin{array}{l}\text { Antibiotic } \\
\text { (pro-drug) }\end{array}$ \\
\hline & Sulfasomidine & $\mathrm{C}_{12} \mathrm{H}_{14} \mathrm{~N}_{4} \mathrm{O}_{2} \mathrm{~S}$ & $\begin{array}{l}\text { 4-amino- } N \text {-(2,6-dimethylpyrimidin-4-yl) } \\
\text { benzenesulfonamide }\end{array}$ & Antibiotic \\
\hline
\end{tabular}


of the synthesis without noticeable loss of yield and shortened the reaction time of the second reaction step from 6 hours to 75 minutes (Scheme 1).

The replacement of THF with water resulted in a somewhat longer reaction time of $90 \mathrm{~min}$ but reduced the cost and the ecological burden and made the reaction safer.

Various changes, such as the use of different chemicals, different preparation steps and variation of the equipment contributed to further shorten the overall duration, so that the whole synthesis can now be performed in 5 hours or, alternatively, can be divided into two steps of 3 hours each.<smiles>CC(=O)Nc1ccccc1</smiles><smiles>O=C(Cl)Nc1ccc(S(=O)(=O)O)cc1</smiles>
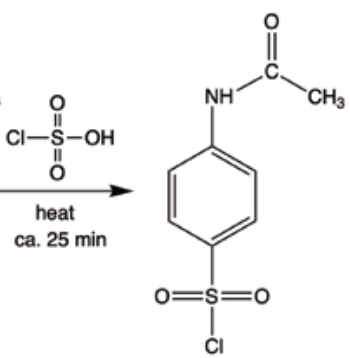
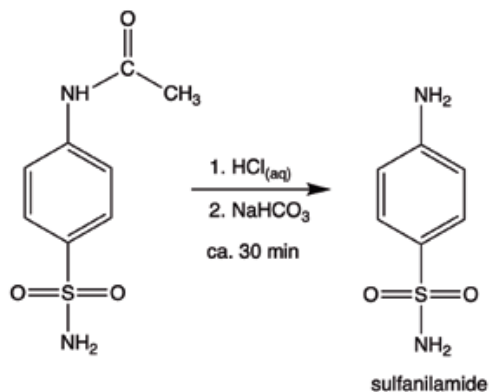

Scheme 1. The synthesis pathway of sulfanilamide as it is used in the teaching unit from 2008. ${ }^{[1]}$ The decisive difference to the synthesis pathway of sulfamethoxazole is the third step, where the simpler sulfanilamide is formed with ammonia.

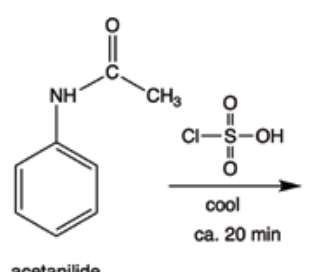<smiles>O=C(Cl)Nc1ccc(S(=O)(=O)O)cc1</smiles>
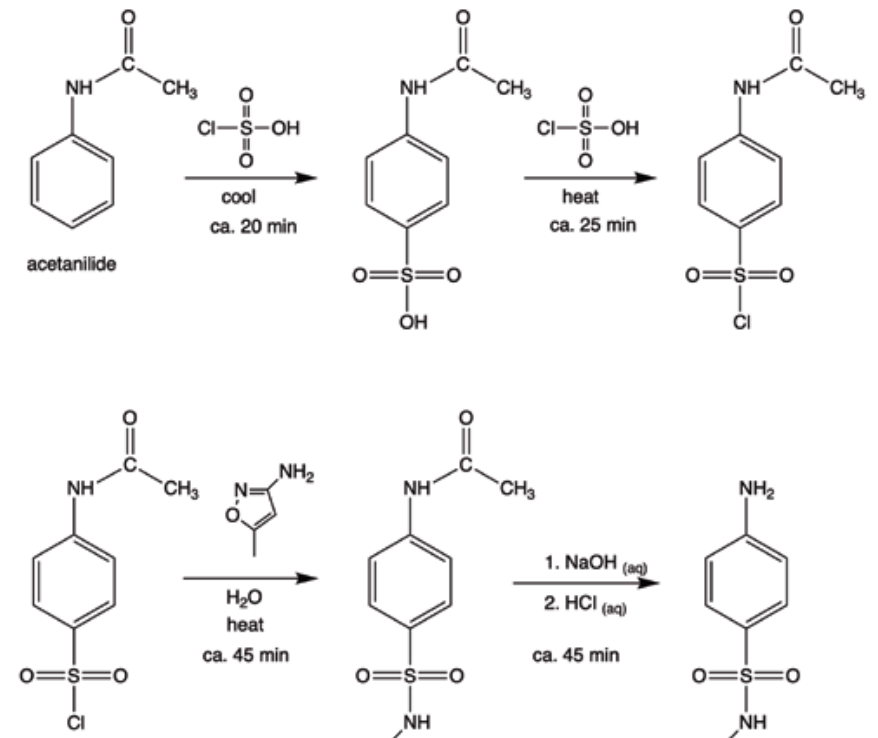
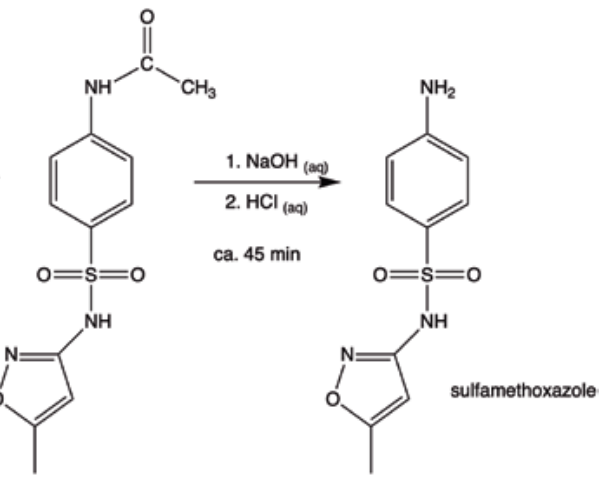

Scheme 2. The synthetic pathway of sulfamethoxazole as the final result of the Matura thesis. The synthesis can be carried out within about five hours, i.e. in one afternoon in a well-equipped school laboratory. It is also possible to divide it into two steps of 3 hours each.
In Scheme 1, the synthetic route to sulfamethoxazole is shown starting from acetanilide. Scheme 2 shows for comparison the synthetic pathway of sulfanilamide.

Since the synthesis of sulfamethoxazole takes about the same time as the synthesis of sulfanilamide, both syntheses can be performed in a school by different groups at the same time. Subsequently, the different properties of the two sulfonamides can be compared.

Infrared Spectroscopy: At first glance, the infrared spectra of the two sulfonamides look very similar (Figs 3 and 4), which is not surprising as both have a similar structure. The only exception is the missing 5-methylisoxazole moiety in sulfanilamide (Fig. 4). However, the infrared spectrum of sulfamethoxazole (Fig. 3) shows three distinct bands of the 5-methylisoxazole ring, two of which are located between the bands of the sulfone groups and the third follows the band of the S-N group.

Melting Point: With the usual laboratory equipment of a secondary school it is probably difficult to distinguish the two substances on the basis of their melting point: The difference is only $2{ }^{\circ} \mathrm{C}$ : Tm (sulfanilamid): $165^{\circ} \mathrm{C}$; Tm (sulfamethoxazole): $167{ }^{\circ} \mathrm{C} \cdot{ }^{[12]}$

Verification of the Antibiotic Effect: Disc Diffusion Test: With a simple disc diffusion test with Bacillus subtilis the students could prove the bacteriostatic effect of both sulfonamides, with sulfamethoxazole showing a much higher potency than sulfanilamide (Fig. 5).

Differences in Side Effects: As mentioned above, sulfanilamide, unlike sulfamethoxazole, shows pronounced side effects and therefore, today, sulfanilamide is only approved for external use in human medicine. A detailed discussion of this difference follows in the next section.

\section{Structure, Effects and Side Effects of Sulfonamides - Introduction to Drug Design}

One of the most important didactic objectives in secondary school chemistry is to explain the properties of substances with the structure of the molecules involved. The question as to why sulfamethoxazole has an antibiotic effect but does not cause side effects such as diuresis was didactically developed and implemented at the Kantonsschule Freudenberg in Zurich.

In a supplementary chemistry course (Ergänzungsfach Chemie), the effect of various drugs whose mechanisms are based on the inhibition of enzymes was investigated in the laboratory. These included allopurinol, a drug for gout that inhibits xanthine oxidase, and acetazolamide, a sulfonamide that inhibits carbonic anhydrase and thus reduces the intraocular fluid pressure in the eye.

The experiment on carbonic anhydrase starts with the isolation of the enzyme from pig blood. The students centrifuge the blood, remove the plasma, denature the hemoglobin and separate the almost colorless carbonic anhydrase solution. The steps can be easily explained and result in clearly visible changes.

The inhibition of the enzyme can be detected with soda water and an acid base indicator. After soda water is mixed with a buffer solution containing phenol red, it takes about 10 seconds until the color changes. Carbonic anhydrase reduces the time to 1 second and inhibitors increase the time to 7 to 10 seconds.

The question of why some sulfonamides inhibit both dihydropteroate synthase (DHPS) and carbonic anhydrase (CA), while others inhibit only one of these enzymes leads to a discussion on how drugs can be developed to be effective and have few side effects and thus initiates an excursion into the field of drug design.

A comparison of the four sulfonamides sulfanilamide, sulfamethoxazole, acetazolamide and dorzolamide shows that the sulfonamide molecules appear to bind to the enzymes dihydropteroate synthase (DHPS) and carbonic anhydrase in different 

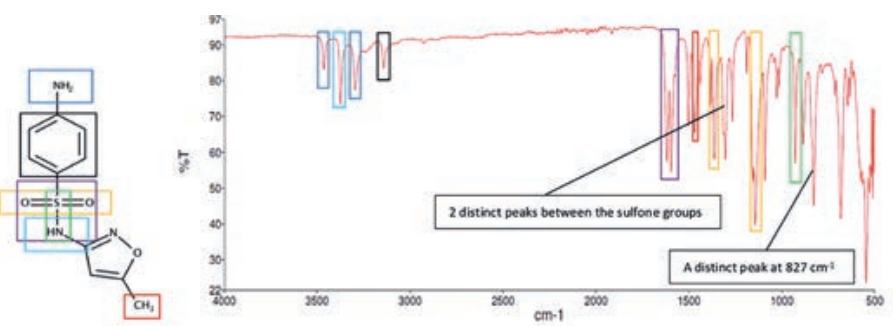

Fig. 3. IR spectrum of sulfamethoxazole (ATR). In comparison with the IR spectrum of sulfanilamide, the spectrum shows 2 distinct bands between the sulfone groups and one band at $827 \mathrm{~cm}^{-1}$

Fig. 5. The antibiotic effect of sulfamethoxazole and sulfanilamide compared: Left: The positive inhibition yard test demonstrates the bacteriostatic effect of sulfamethoxazole at two different concentrations. Center: Different concentrations of sulfamethoxazole were applied on the left side, and the same concentrations of sulfanilamide on the right side. The larger inhibition sites on the left side indicate the stronger antibiotic effect of sulfamethoxazole.

Right: Negative control

ways: The amino group seems to be significantly involved in the binding with DHPS and thus responsible for the antibiotic effect. In contrast, the sulfonamide group seems to be essential for binding to carbonic anhydrase (CA). (see Fig. 6).

Since sulfanilamide contains both groups, it binds to both enzymes - and therefore when used as an antibiotic, causes the adverse side effects due to the inhibition of CA. The selectivities of sulfamethoxazole as an antibiotic and acetazolamide as a CA inhibitor are achieved with substituents that make it impossible to bind to either of the enzymes for steric reasons.

However, acetazolamide is not entirely convincing for many medical applications: because carbonic anhydrase is present in different parts of the body, inhibition has several effects, of which only one is desirable.

In such cases, local application is ideal - in the case of glaucoma, for example, as eye drops. For many years, it seemed impossible to use sulfonamides as eye drops, as the derivatives known at that time could not penetrate the eye from outside. After a locally active carbonic anhydrase inhibitor was synthesized for the first time in 1983, the lipophilicity range could be characterized, which allowed the uptake into the eye, whereupon the inhibitor could be optimized with molecular modelling. The result, dorzolamide, passed all clinical trials and is probably the first example of a drug created by structurebased drug design. Dorzolamide fulfils the requirements for a good drug. Because it is administered in the form of eye drops, it acts locally. The carbonic anhydrase in other organs is not affected. ${ }^{[13,14]}$

This didactic concept combines the field of drug design, which is central to the research, with the structure-activity relationships which are central to the high school chemistry and shows how fruitful an interdisciplinary approach between chemistry and biology/medicine can be.

However, an important aspect still needs to be added so that students can develop a deep chemical understanding of the pharmacological effects of sulfonamides. An aspect which clearly shows an important difference between the viewpoints for biology and chemistry: While in high school biology lessons, geometrically simplified analogies are often used to 'explain' whether an inhibitor binds to an enzyme or not, the chemical point of view goes a decisive step further and asks which interactions cause or
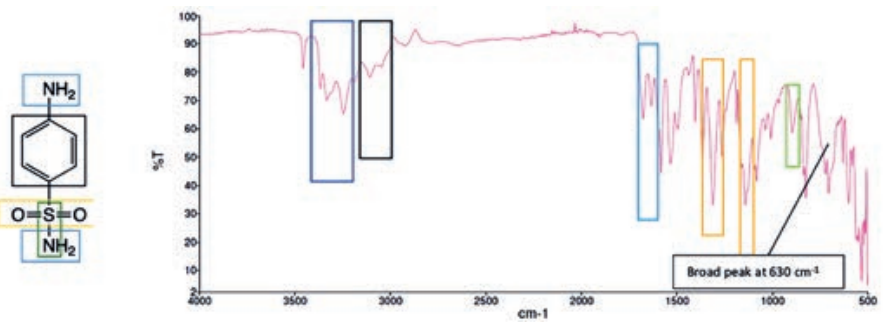

Fig. 4. IR spectrum of sulfanilamide (ATR) In comparison with the IR spectrum of sulfamethoxazole, the spectrum shows a prominent broad band at $630 \mathrm{~cm}^{-1}$

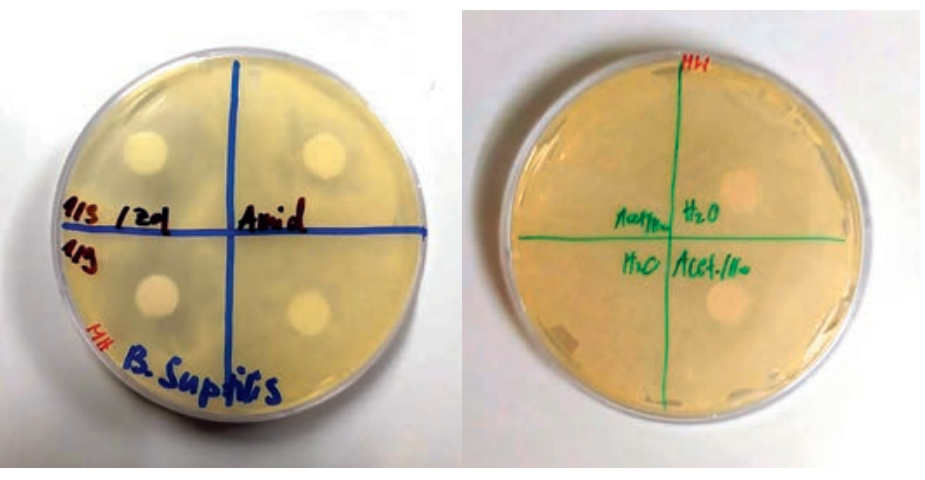

prevent the binding to an enzyme: interactions such as hydrogen bonds and hydrophobic effects or steric hindrance play an important role here. The didactic development of this last central area which leads by the use of modern digital methods of molecular modelling to the center of drug design, was developed at the Kantonsschule Zug.

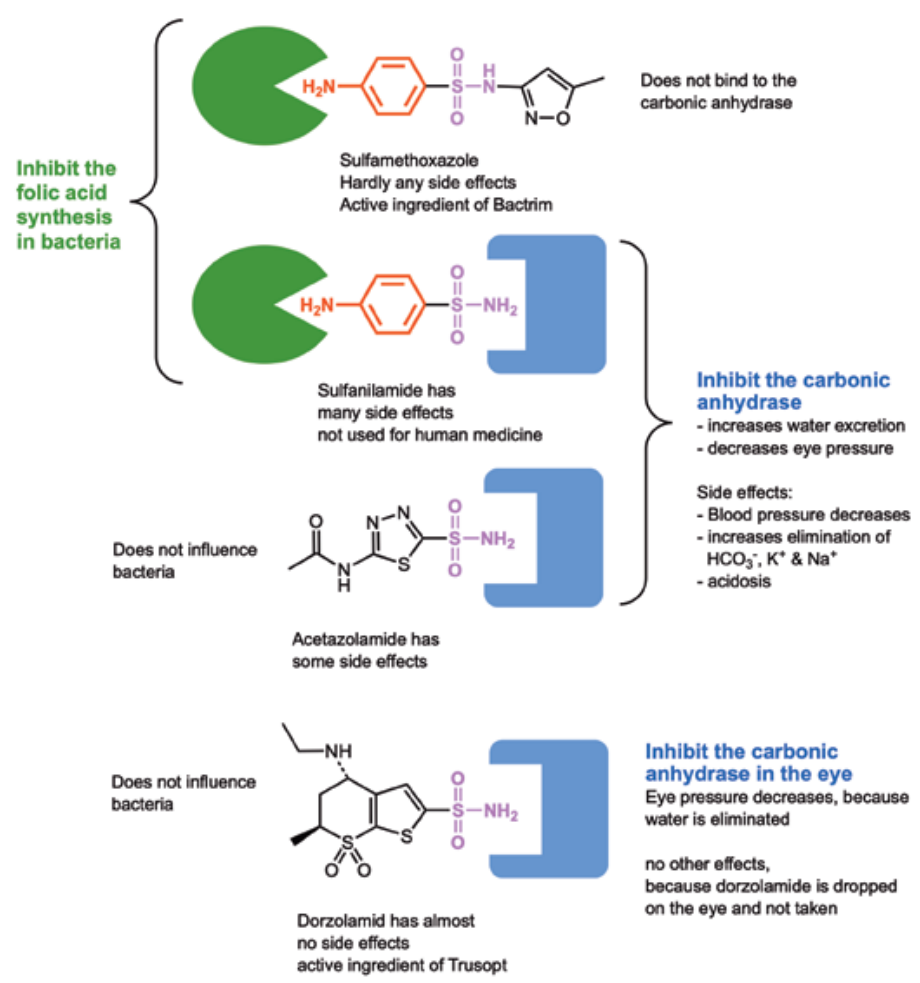

Fig. 6. In humans, sulfonamides inhibit carbonic anhydrase. In bacteria, sulfonamides inhibit the formation of folic acid. The effect can be controlled with suitable groups: The dihydropteroate synthase DHPS, which only occurs in bacteria, is shown in green. The human carbonic anhydrase is shown in blue. 


\section{Selectivity and Molecular Modelling: What Makes a Good Inhibitor}

For several years, chemistry teachers at the Kantonsschule Zug have been using 3D-models to give students an idea of the world of atoms as concrete as possible. They make use of the molecular modelling pages of Swisseduc ${ }^{[15]}$ and apply 3Dmol and JSmol in moodle exercises. ${ }^{[16,17]}$

The versatile inhibitor sulfanilamide is a very good starting point for such an exploration tour into the world of atoms. It can be used to illustrate and apply a great number of basic concepts at different levels of explanation. We have therefore developed a website on Swisseduc where the students can interactively work on some aspects of sulfonamide inhibitors. ${ }^{[2]}$

Dihydropteroate synthase (DHPS) is inhibited competitively by sulfanilamide, thus indicating that sulfanilamide replaces the substrates in some way. This in turn implies that sulfanilamide resembles one of the substrates in relevant ways. In a first step, the students therefore compare sulfanilamide with the substrates and figure out which might be the decisive traits, an approach that is also taken by professionals. ${ }^{[14]}$ Even though sulfanilamide is uncharged and 4-aminobenzoate is an anion, the two molecules share a similar shape, comparable charge distributions and allocations of hydrogen bond acceptors and donors as well as hydrophobic patches (Fig. 7). Sulfanilamide offers the students a good opportunity to practice the important skill of how to translate the abstract structural formulas into particle properties.

In a next step, these findings are used to dock sulfanilamide to the catalytic center of DHPS using the browser-based 3D visualization app JSmol.[16] This task is considerably simplified by the bound substrate that serves as an orientation aid. If the docking is done correctly, JSmol predicts very similar hydrogen bonds for the enzyme complexes of sulfanilamide and the substrate respectively, confirming the earlier considerations.

Today, sulfanilamide has only very limited use as an antibiotic because it inhibits both the bacterial DHPS - which makes it an antibiotic - and the human carbonic anhydrase CA, thus giving rise to multiple physiological effects (section 3 ). Whichever of these effects is desired, the other one is adverse. Nevertheless, sulfanilamide has been developed into really powerful drugs by modifying it to form molecules that only inhibit either DHPS or CA. The next step for the students is to see how such a drug could be optimized and why this goal was not quite so easy to achieve. The
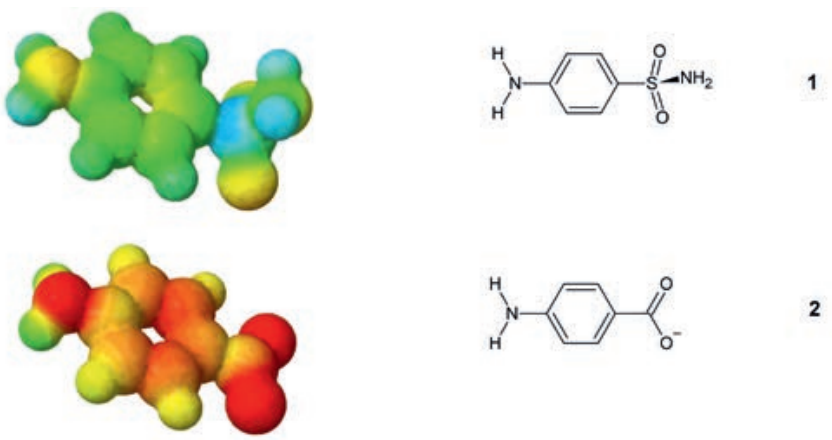

2
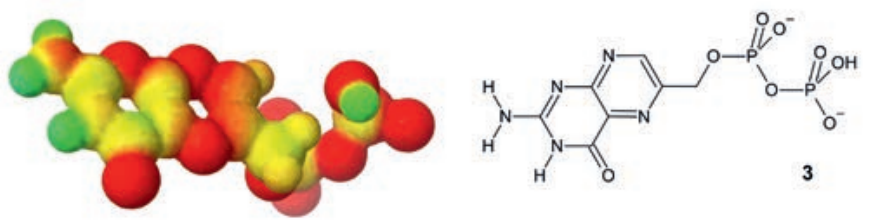

Fig. 7. Sulfanilamide (1) and the two DHPS substrates 4-aminobenzoic acid (2) and 6-hydroxymethylpterin diphosphate (3). Colors indicate (partial) charges, yellow and red regions being negatively charged, green regions neutral and cyan and blue regions positively charged. students analyze the molecules in their binding pockets, record hydrogen bonds and hydrophobic interactions and sketch where the molecules have direct contact to the cytosol (Fig. 8 and 9).

The basic idea of section 3 can be extensively confirmed. While the amino group of sulfanilamide is deeply buried inside DHPS, it is comparatively accessible from the cytosol in CA. The reverse is true for the sulfonamide group. But the closer inspection also reveals that the situation is more complicated than originally thought. In fact, in DHPS, almost the whole molecule is buried inside the enzyme and resides in tight contact with protein residues, and the solvent contact of the bound inhibitor is rather restricted (Fig. 8). Only the amine part of the sulfonamide group points towards the cytosol and opens up the opportunity of modifying the molecule without losing the affinity towards DHPS. The clear situation allows the students to decide from a set of similar molecules which ones would also fit into the reactive center of DHPS and which ones would not.
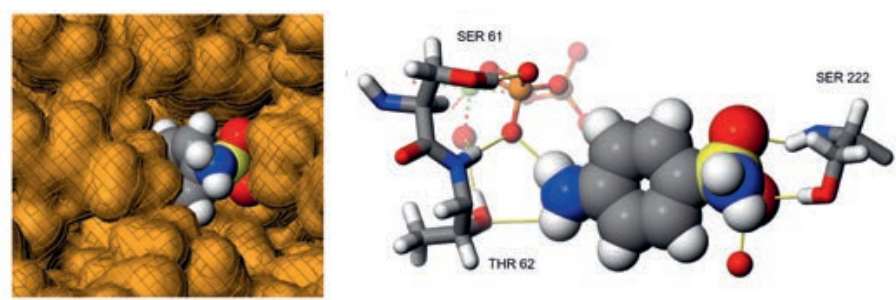

Fig. 8. Sulfanilamide as it is bound by DHPS. The interactions with hydrophilic residues and automatically assigned hydrogen bonds are shown in the right panel, the surrounding protein in a similar orientation in the left panel. Only the amino part of the sulfonamide group points towards the cytosol. Blended from PDB structures 1AJ0 and 3TZF.
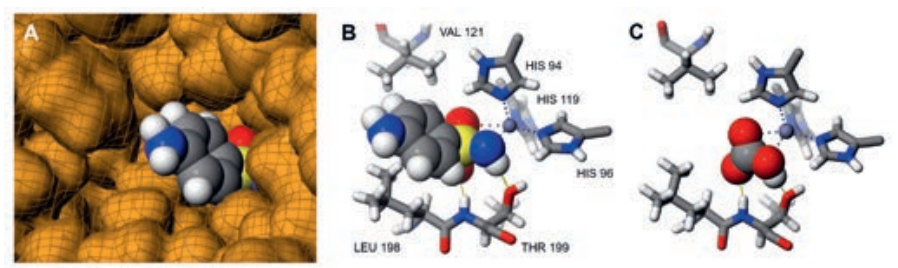

Fig. 9. A and B: sulfanilamide as it is bound by human carbonic anhydrase II, hCAIl. While the whole sulfonamide group is deeply buried inside the enzyme, the amino group points towards the cytosol, and the binding pocket is considerably wider than that of the DHPS. C: Interaction of hydrogen carbonate with CA. Due to the similar binding situation, sulfonamide inhibitors are considered as transition state analogs. PDB structures 6RL9 and 1BIC.

This leads to the next task. Based on their notes and by docking sulfamethoxazole to the two enzymes, the students investigate why sulfamethoxazole is an antibiotic with much fewer side effects than sulfanilamide.

In a last task, they can try to select from a series of molecules that should bind only to one of the enzymes (Fig. 10). These selective inhibitors should form the same interactions with the target, but they can carry additional bulky groups that sterically hinder binding to the other enzyme.

This task is considerably more difficult than the previous ones, because the students must be able to handle molecule models quite skillfully. They need to be able to quickly recognize hydrogen bonds, hydrophobic areas and other traits and apply them to the binding situation. The selection of molecules includes potent inhibitors to both CA and DHPS respectively. Once the task is accomplished, the students can check their predictions by having the intermolecular interactions shown and the enzyme pocket drawn as a surface. Which molecules would the students select for 


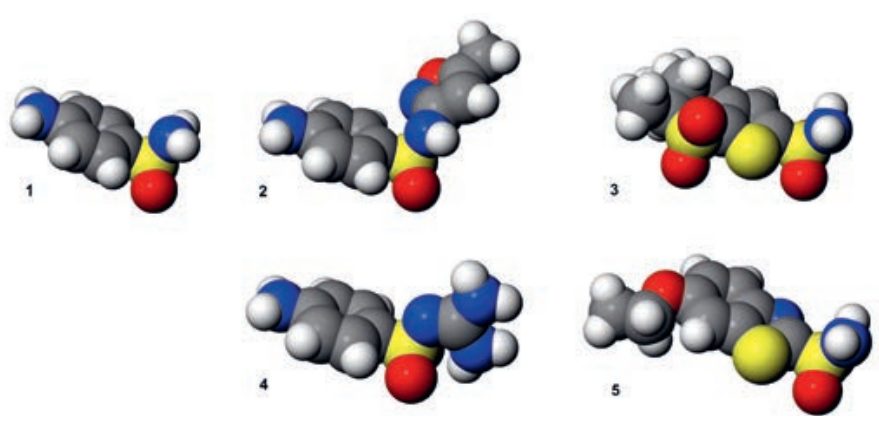

Fig. 10. Sulfanilamide, sulfamethoxazole, dorzolamide, sulfaguanidine and ethoxzolamide. Which molecule fits inside which binding pocket?

a further development into an antibiotic or a diuretic? To a certain extent, they can experience how an inhibitor strongly binds to an enzyme, how it must fit well into the binding pocket and how this fact can be used to develop specific inhibitors.

Besides, CA is especially well suited for this task because its binding pocket is comparably rigid (Fig. 11). This means that whichever X-ray structure is used as a template, all CA inhibitors fit reasonably well. More flexible enzymes like DHPS yield more equivocal docking results. Interestingly, this rigidity of CA has yet another twist that makes the docking results especially meaningful. When parts of an enzyme change conformation upon binding, this usually comes at some energetic cost. In addition, inhibitor binding imposes restrictions on the flexible residues that are entropically unfavorable. Both the enthalpic and entropic penalties can be difficult to quantify and their discussion is probably out of reach for the classroom. For a rigid enzyme such effects need not to be modelled (rigid body assumption) ${ }^{[18,19]}$ and it is valid to neglect them. The rigidity of CA has also recently proven helpful in the discovery of the key role of water molecules for the binding thermodynamics and affinities of inhibitors. [20]

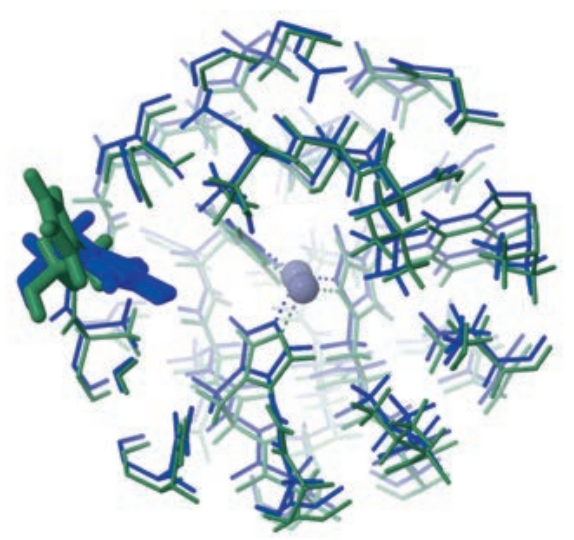

Fig. 11. Rigidity of the CA catalytic center. Green: CA bound by dorzolamide (inhibitor not shown). Blue: CA where the catalytic region only contains water. In spite of the very different binding partners of the two enzymes, most of the residues hardly change position. The only residue that flips to a different position upon inhibitor binding is His-64 (to the left, depicted in slightly bigger bond and sphere radii). The flexibility of this residue is essential for the proton shuttling by His-64 out of the reactive center. PDB structures 3TMJ and 6BC9.

\section{How to Make a Better Inhibitor}

So far, it seems that the development of a good inhibitor is a rather straightforward matter. But why has it then in many cases proved so difficult to refine inhibitors? ${ }^{[21]}$ How is it that sometimes such strange things happen as that when researchers enable additional hydrogen bonds between inhibitors and enzymes, this can even lower the inhibitor affinity? ${ }^{[22]}$ In fact, why is it still not possible to predict affinity or other binding parameters for a novel inhibitor reliably by computational methods alone? ${ }^{[18]}$ Why do certain inhibitors with quite similar geometries and hydrogen bonding show quite different affinities, such as the inhibitors acetazolamide und methazolamide in some CA isoforms? ${ }^{\text {[18] }}$

We have reached a point that is typical for chemistry teaching. We have explored a didactically secured example that nicely illustrates and slightly extends important and well-known concepts. But some open questions remain, and if the students do not stop asking here, matters might well become very complicated. Below we describe some aspects that can arise in the discussion of inhibitor binding and other central biochemical topics like stability of the DNA double helix, of lipid bilayers or folded proteins. We feel that it can be very valuable to discuss some of these aspects with students. Others are far too complicated and most of them are full of pitfalls.

- Why should hydrogen bonds lead to a tight binding of an inhibitor in the first place? This is a central issue that also arises in other contexts, e.g. DNA base pairing. Before binding to each other, enzyme pockets and inhibitors are surrounded by water and both are engaged in various hydrogen bonds. The energy that is needed to remove the surrounding water molecules can be of the same order of magnitude as the bond energy of the hydrogen bonds between enzyme and inhibitor and can even cause unfavorable binding enthalpies. ${ }^{[22]}$ In addition, hydrogen bonds can lower the affinity by restricting the flexibility of either enzyme or inhibitor. This is an example for the widespread phenomenon of improved binding enthalpies being compensated by unfavorable entropy changes and vice versa. ${ }^{[22]}$ Nevertheless, a well-placed hydrogen bond can make a favorable enthalpic contribution of about -17 to $-21 \mathrm{~kJ} / \mathrm{mol}$, which is equivalent to a $1000-5000$-fold increase in affinity. On the Swisseduc pages, students can compare bond lengths and angles of the inhibitor/enzyme complexes to the lengths and angles of hydrogen bonds in other structures. Indeed, sulfonamides form quite optimally oriented, strong interactions so that their binding to enzymes is mainly enthalpy driven (see below).

- Another effect that can be discussed is the influence of the acidity constant of the inhibitors. Sulfonamide inhibitors can bind $\mathrm{CA}$ even stronger, the lower their $\mathrm{pK}_{\mathrm{A}}$ lies because they have to release a proton in order to bind to the zinc cation. The effect can be very pronounced. [23] This discussion would shift the attention from a rather static model of binding to a more dynamic model that brings chemical equilibria into play.

- How do we know which of these effects are mainly responsible for binding? This question is very relevant for the improvement of drugs. In addition, it would serve the purpose of not simply imparting facts, but also showing the students where the relevant findings come from. In this context, however, this question is very

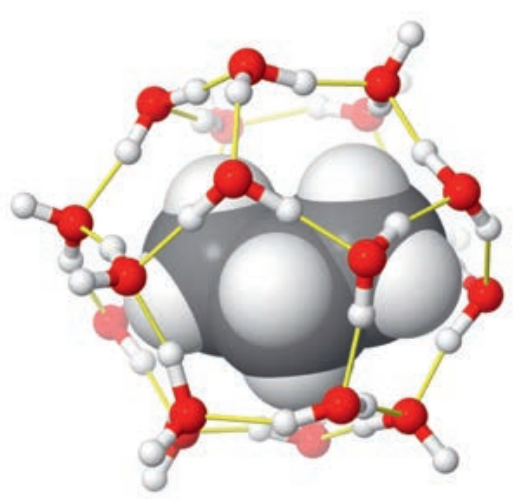

Fig. 12. Water molecules can form a network of hydrogen bonds around small hydrophobic solutes. 
hard to address. The prevalent concepts are largely based on thermodynamic data collected by methods like isothermal titration calorimetry (ITC). ${ }^{[19]}$ The measured binding enthalpies have long been attributed to intermolecular interactions between enzyme and inhibitor, while favorable binding entropies were thought to be a sign for the hydrophobic effect. This effect is explained by increased order of the water molecules around nonpolar solutes (Fig. 12). ${ }^{[22,24]}$ Upon inhibitor binding, these water molecules are released to become less ordered bulk water. The effect has been successfully used to optimize inhibitor affinities by hydrophobic substituents. ${ }^{[22,25]}$ However, the true nature of the hydrophobic effect remains poorly understood. [20] An increasing number of studies, some of them making use of the rigid catalytic center of CA, show that binding of hydrophobic molecules can also have opposite enthalpic and entropic effects. ${ }^{[20,21,26]}$ Possibly, water molecules inside hydrophobic cavities may be forced to sacrifice hydrogen bonds and assume entropically favorable, enthalpically unfavorable states.

While we think that it can be helpful for teachers to be aware of the complex issues, this topic is not suitable for the classroom. Even just the suggested equivalence of binding energy at the atomic level and macroscopic enthalpy change can actually be misleading. It is a hotly discussed topic among Swiss high school teachers how much simpler thermodynamic findings can be profitably adapted for school. ${ }^{[27,28]}$

So, if the affinities of inhibitors are so difficult to understand, how is a rational drugs design even possible? A beautifully successful example is the CA inhibitor dorzolamide (see section $3)^{[14]}$ When the first X-ray structures of carbonic anhydrases became available in the mid-1980, first efforts were undertaken to optimize the then known inhibitors. The first result was thienothiopyron-sulfonamide (MK 927, Fig. 13).
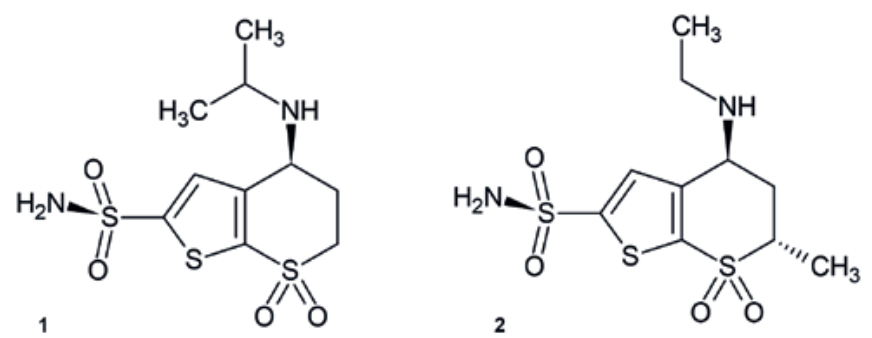

Fig. 13. Thienothiopyron-sulfonamide (MK 927) and dorzolamide

The X-ray structure of this molecule bound to CA revealed that the isopropylamino group had to adopt an energetically unfavorable axial orientation in the enzyme pocket (Fig. 14). To improve the affinity, this axial orientation was stabilized by an additional equatorial methyl group. The increased hydrophobicity of the resulting molecule was balanced out by replacing the isopropyl group by an ethyl group. These steps together increased the affinity by a factor of 2 and the result, dorzolamide, is now a widespread CA inhibitor in eye drops.

Fig. 14. A,B) Thienothiopyronsulfonamide (MK 927) and dorzolamide as they are bound by CA. C) Dorzolamide inside the CA binding site. The groups that are modified in comparison to MK 927 are circled.

\section{Conclusions}

Sulfonamides are excellently suited to be included in the chemistry curriculum of secondary schools. This text demonstrates that many chemical and biological concepts can be included, thereby teaching them in a fascinating way:

Organic synthesis: Students can synthesize sulfonamides in the lab on their own, later identifying them using IR spectroscopy.

Medical effect: Drugs often harness the selectivity of enzymes, thus targeting specifically the cause of a disease: Sulfonamides are bacteriostatic agents, specifically inhibiting an enzyme that is present in bacteria but not in humans.

Experimental proof of the effect of a drug: a) Sulfonamides inhibit the growth of bacteria on agar plates; b) Sulfonamides inhibit the enzyme carbonic anhydrase and delay the color change of an indicator.

Structure-activity relationship: Comparing the structure of several different sulfonamides allows to understand the reasons for side effects and, simultaneously, how they can be avoided.

Lock-and-key principle: Computer-aided molecular modelling shows how pharmaceutical agents can be optimized. Hydrogen bonds, hydrophobic interaction and the spatial form are most crucial in this respect.

In practice, it is important that sulfonamides can be discussed in their entirety as well as in individual aspects. The suggested modules can therefore be used as individual components, independently of each other. Moreover, they are thought to be used in a variety of settings: lab experiments, study weeks, self-study

\section{Online Teaching Resources}

All the teaching units mentioned in this article can be downloaded free from the educational server Swisseduc with this link:

https://www.swisseduc.ch/chemie/sulfonamide

- Synthese von Sulfamethoxazol - a lab course for students

- Synthese von Sulfanilamid - a lab course for students

- Infrarot-Spektroskopie - a course for the analytics of sulfanilamide and sulfamethoxazol

- Bakterientest - a lab course for students

- Hemmung der Carboanhydrase - a lab course for students

- Wirkstoffdesign: Wirkungen und Nebenwirkungen von Medikamenten - Didactical reflections

- Drug design using molecular modelling (Interactive tasks for students)

- Docking of sulfanilamide to the enzyme dihydropteroate synthase DHPS

- Analysis of the interactions between sulfanilamide and the enzymes DHPS and carbonic anhydrase CA

- Docking of sulfamethoxazole to the enzymes DHPS and CA

- Docking of different inhibitors to the enzymes DHPS and CA

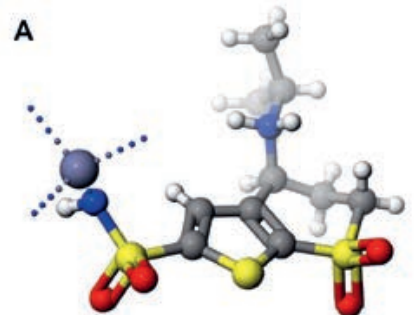

B

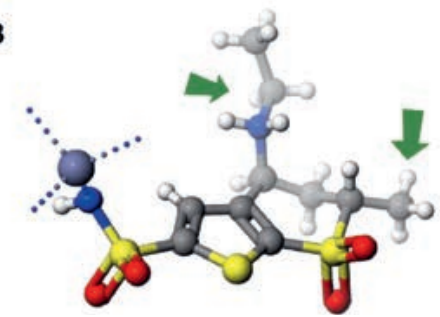

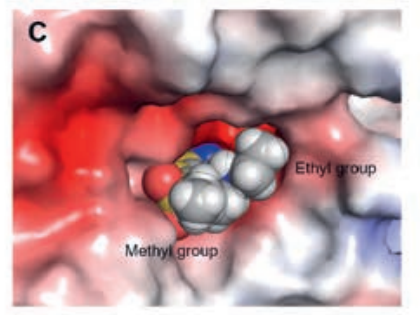


blocks, as a contribution to the digitization and finally, as an interdisciplinary course with biology or history. Given enough time, like in a major subject, all the discussed modules can be joined to form a fascinating topic.

Received: November 16, 2021

[1] R. Deuber, P. Kaeser, J. Lipscher, PdN-ChiS 2008, 57, 45.

[2] SwissEduc - Chemie, 'Sulfonamide als Antibiotika: Wirkung und Synthese', https://www.swisseduc.ch/chemie/sulfonamide/, accessed November 9, 2020.

[3] N. Bloesch, Matura Thesis, Gymnasium Alpenstrasse, Biel, 2013.

[4] J. Widmer, Matura Thesis, Kantonsschule Trogen, 2015.

[5] J. E. Lesch, 'The First Miracle Drugs: How the Sulfa Drugs Transformed Medicine', Oxford University Press, 2007.

[6] G. H. Schneller, Drug Dev. Ind. Pharm. 1977, 3, 131.

[7] Drugs.com I Prescription Drug Information, Interactions \& Side Effects, https://www.drugs.com/, accessed November 13, 2020.

[8] CliniPharm: https://www.clinipharm.ch/ ISSN: https://www.vetpharm.uzh.ch/, accessed November 13, 2020.

[9] R. Meyer, F. Hürst, Matura Thesis, Kantonsschule Baden, Eigenverlag, 2018.

[10] L. Wang, L. Li, Z.-H. Zhou, Z.-Y. Jiang, Q.-D. You, X.-L. Xu, Eur. J. Med. Chem. 2017, 136, 63, https://doi.org/10.1016/j.ejmech.2017.04.074.

[11] K. R. Brimacombe, M. J. Walsh, L. Liu, M. G. Vásquez-Valdivieso, H. P. Morgan, I. McNae, L. A. Fothergill-Gilmore, P. A. Michels, D. S. Auld, A. Simeonov, ACS Med. Chem. Lett. 2014, 5, 12, https://doi.org/10.1021/ml400259d

[12] Gefahrstoffe:

GESTIS-Stoffdatenbank, https://www.dguv.de/ifa/gestis/gestis-stoffdatenbank/, accessed November $13,2020$.

[13] H.-J. Böhm, G. Klebe, Angew. Chem. 1996, 108, 2750, https://doi.org/10.1002/ange.19961082205.

[14] G. Klebe, 'Drug Design: Methodology, Concepts, and Mode-of-Action', Springer-Verlag, Berlin Heidelberg, 2013.

[15] Swisseduc Molekularium: https://www.swisseduc.ch/chemie/molekularium/index.htm.

[16] 'JSmol: an open-source HTML5 viewer for chemical structures in 3D', http://wiki.jmol.org/index.php/JSmol.
[17] '3Dmol. WebGL based JavaScript library for online molecular visualization', http://3dmol.csb.pitt.edu/.

[18] V. Linkuvienè, A. Zubrienè, E. Manakova, V. Petrauskas, L. Baranauskienè, A. Zakšauskas, A. Smirnov, S. Gražulis, J. E. Ladbury, D. Matulis, Q. Rev. Biophys. 2018, 51, e10, https://doi.org/10.1017/S0033583518000082.

[19] R. Perozzo, G. Folkers, L. Scapozza, J. Recept. Signal Transduct. 2004, 24 , 1, https://doi.org/10.1081/RRS-120037896.

[20] P. W. Snyder, J. Mecinovic, D. T. Moustakas, S. W. Thomas, M. Harder, E. T. Mack, M. R. Lockett, A. Heroux, W. Sherman, G. M. Whitesides, Proc. Natl. Acad. Sci. USA 2011, 108, 17889, https://doi.org/10.1073/pnas.1114107108

[21] S. Geschwindner, J. Ulander, P. Johansson, J. Med. Chem. 2015, 58, 6321, https://doi.org/10.1021/jm501511f.

[22] E. Freire, Drug Discov. Today 2008, 13, 869, https://doi.org/10.1016/j.drudis.2008.07.005.

[23] L. Baranauskiene,, D. Matulis, BMC Biophys. 2012, 5, 12 , https://doi.org/10.1186/2046-1682-5-12.

[24] K. A. Dill, S. Bromberg, 'Molecular driving forces; Statistical Thermodynamics in Biology, Chemistry, Physics, and Nanoscience', Garland Science, London and New York, 2010.

[25] A. Jain, G. M. Whitesides, R. S. Alexander, D. W. Christianson, J. Med. Chem. 1994, 37, 2100, https://doi.org/10.1021/jm00039a023.

[26] M. R. Lockett, H. Lange, B. Breiten, A. Heroux, W. Sherman, D. Rappoport, P. O. Yau, P. W. Snyder, G. M. Whitesides, Angew. Chem. Int. Ed. 2013, 52, 7714, https://doi.org/10.1002/anie.201301813.

[27] H. Dütsch, $C+B-Z$. VSN 2018, 3, 16

[28] R. Deuber, $C+B-Z$. VSN 2018, 3, 20 .

\section{License and Terms}

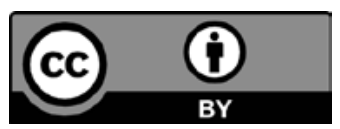

This is an Open Access article under the terms of the Creative Commons Attribution License CC BY 4.0. The material may not be used for commercial purposes.

The license is subject to the CHIMIA terms and conditions: (http:// chimia.ch/component/sppagebuilder/?view=page \&id=12).

The definitive version of this article is the electronic one that can be found at https://doi.org/10.2533/chimia.2021.80 